\title{
ANALISIS KELAYAKAN INVESTASI PERBAIKAN KUALITAS PELAYANAN DI AJB BUMI PUTERA 1912 CABANG SIDOARJO
}

\author{
YUSTINA NGATILAH, ${ }^{1}$ DAN C. INDRI PARWATI ${ }^{2}$ \\ ${ }^{1}$ Teknik Industri, UPN "Veteran” Jawa Timur, \\ ${ }^{2}$ Teknik Industri Institut Sains dan Teknologi, AKPRIND Yogyakarta \\ E-mail: yustinangatilah@yahoo.co.id; yustinangatilah@gmail.com
}

\begin{abstract}
ABSTRAK
Kepuasan pelanggan adalah sangat penting untuk dipertimbangkan oleh setiap perusahaan, baik jasa dan produksi, sehingga pelanggan tidak beralih ke pesaing, dan kepuasan pelanggan selalu berubah sesuai dengan zaman atau era pembangunan manusia. Dalam hal ini kepuasan pelanggan yang berubah, kita perlu program peningkatan kualitas. Penelitian ini menggunakan metode ROQ (Retrun On Quality), yaitu, metode yang digunakan untuk pengambilan keputusan akan meningkatkan kualitas program yang diusulkan, dapat diterapkan atau tidak. ROQ sangat dipengaruhi oleh jumlah kepuasan pelanggan, retensi pelanggan dan biaya program yang diusulkan peningkatan kualitas. Program yang diusulkan menggunakan IP grafik pemetaan untuk menentukan peningkatan kualitas. Dari hasil, menunjukkan peningkatan kepuasan pelanggan dan retensi pelanggan yang masing-masing adalah $80,41 \%$ menjadi $81.22 \%$ dan $24,56 \%$ sampai 28,56\%, yang mencapai panggung. Proposal ini layak untuk program peningkatan kualitas terbaik. Dengan menggunakan pertumbuhan data pasar, data pangsa pasar, keuntungan rata-rata agen dan tingkat bunga pada horizon perencanaan, maka perhitungannya dapat dilakukan ROQ. Perhitungan ROQ yang membutuhkan perhitungan NPV, NPVO, NPVAS yang dilakukan sebagai horizon perencanaan 5 periode berikutnya. Dari hasil perhitungan, diperoleh NPV Rp.152.636.602.289, 00; NPV0 untuk Rp.145.407.658.197, 00, dan NPVAS dari Rp.3.573.189.670, 00; sehingga nilai ROQ adalah 2,0231. Hasilnya diperoleh bahwa usulan tersebut adalah kualitas program perbaikan yang layak untuk diimplementasikan, sampai tingkat mencapai $46,457 \%$.
\end{abstract}

Kata kunci: Return on Quality, NPV (Net Present Value)

\begin{abstract}
Customer satisfaction is very important to be considered by every company, both service and production, so customers do not switch to the competitors, and customer satisfaction is always changing according to the era or the era of human development. In terms of customer satisfaction that this changing, we need quality improvement program. This study used the method ROQ (Retrun On Quality), namely, the methods used for decision making will improve the quality of the proposed program, can be applied or not. ROQ is mostly influenced by the amount of customer satisfaction, customer retention and cost of the proposed program of quality improvement. The proposed program used graph mapping IP to determine the quality improvement. From the results, shows an increase in customer satisfaction and customer retention which respectively is $80.41 \%$ to $81.22 \%$ and $24.56 \%$ to $28.56 \%$, which reached the stage. These proposals deserve to the best quality improvement program. By using the data market growth, market share data, the average benefits agents and the interest rate at the planning horizon, then the calculation can be done ROQ. ROQ calculations is requiring the calculation of NPV, NPVO, NPVAS which conducted as a planning horizon of next 5 periods. From the calculation results, obtained NPV Rp.152.636.602.289, 00; NPVO for Rp.145.407.658.197, 00; and NPVAS of Rp.3.573.189.670, 00; so ROQ value was 2.0231. The result obtained that the proposal is feasible quality improvement program to be implemented, until rate reached $46.457 \%$.
\end{abstract}

Key words: Return on Quality, NPV

\section{PENDAHULUAN}

Kepuasan pelanggan adalah hal utama yang harus diperhatikan oleh setiap perusahaan karena jika pelanggan merasa tidak puas dengan produk yang ditawarkan oleh perusahaan tersebut maka pelanggan tersebut akan beralih keperusahaan lain (Garperz, 2002). Pada suatu perusahaan yang menawarkan jasa, akan sangat terlihat sekali akan usaha pemuasan kebutuhan konsumen tersebut (Kofler, 1999).

AJB Bumi putera 1912 (cabang Sidoarjo) merupakan salah satu perusahaan yang bergerak dibidang jasa, yang secara detail menawarkan jasa berupa asuransi kesehatan (jiwa), sehingga dalam 
menawarkan jasa tersebut AJB Bumi putera 1912 (cabang Sidoarjo) sangat perlu memperhatikan mutu pelayanan yang diberikan kepada nasabahnya (Hartono, 1995). Persaingan pada bisnis asuransi saat ini mengarah ke kompetisi yang timbul sebagai dampak dari kemajuan teknologi dan perubahan kebutuhan pasar sehingga lingkungan bisnis masa depan akan sangat lebih kompetitif dalam meraih pangsa pasar (market share). Hal ini menuntut pihak menejemen perusahaan untuk bersikap kritis terhadap faktor-faktor seperti retensi, dimana retensi merupakan tolok ukur untuk mengetahui tingkat kepuasan dan tingkat loyalitas yang tinggi terhadap suatu produk atau layanan (Dharmawan, 2000). Kualitas dalam hal ini sangat berkaitan erat dengan mutu pelayanan yang diberikan oleh pesaingpesaingnya seperti Sinarmas assurance dan Bumi Asih assurance yang keduanya terletak di Sidoarjo, sehingga terlihat persaingan bisnis asuransi yang sangat menonjol. Kualitas yang diberikan masingmasing perusahaan tersebut dapat dikatakan hampir sama karena ketiga asuransi tersebut bergerak di bidang yang sama (bisnis asuransi jiwa).

Pengukuran kualitas di AJB Bumi putera 1912 selama ini sebatas memberikan kepuasan terhadap konsumennya tanpa memperhatikan loyalitas pelanggan (retention). Karena lebih penting pelanggan yang loyal dari pada pelanggan yang puas, sehingga demi memberikan layanan yang mampu membuat pelanggan menjadi loyal, maka perlu diketahui hal-hal apa saja yang dibutuhkan oleh konsumen dalam memenuhi kebutuhannya (kepuasan konsumen), yaitu dengan memetakan performansi dan kepentingan variabel-variebel yang sangat berpengaruh terhadap kualitas layanan di AJB Bumi putera 1912. Dengan demikian dapat diketahui program peningkatan kualitas dari variabel yang dianggap kurang baik olah pelanggan, yang secara tidak langsung berpengaruh pada loyalitas pelanggan terhadap perusahaan tersebut. Tujuan dari penelitian ini adalah mengetahui kelayakan investasi perbaikan kualitas pelayanan berdasarkan tingkat kepuasan konsumen,tingkat retensi pelanggan serta nilai ROQ.

\section{METODE}

Pada penelitian ini terurai langkah-langkah pengerjaan adalah sebagai berikut: Tahap awal memulai penelitian ini adalah mengindetifikasi gejala permasalahan yang muncul/terlihat di perusahaan, selanjutnya merumuskan masalahnya. Dari rumusan masalah selanjutnya ditetapkan tujuan penelitian. Berdasarkan tujuan tersebut ditentukan variabel yang berpengaruh.
Tahap pengumpulan data, dilakukan dengan menyebarkan kuisioner (bagian 1) tentang tingkat kepuasan dan tingkat kepentingan konsumen. Penyebaran kuisioner sejumlah sample yang diperlukan untuk mengukur kepuasan konsumen terhadap pelayanan perusahaan (Gaspersz, 2002). Kemudian setelah disebar kuisioner dan didapat data, maka langkah selanjutnya adalah melakukan pengukuran kepuasan yang dirasakan konsumen. Dalam hal ini digunakan dua alat pengukuran yaitu graphic importance \& performance dan customer satisfaction index (CSI) (Parasuranman, A., dkk. 1990). Perhitungan retensi pelanggan melalui data kuisioner loyalitas pelanggan pertanyaan no.17 dan 18. Setelah diketahui atribut-atribut yang perlu diperbaiki serta nilai kepuasan konsumen secara keseluruhan, maka dilakukan perhitungan retensi pelanggan untuk mengetahui besar retensi pelanggan yang terjadi di perusahaan tersebut dengan layanan yang telah dilakukan perusahaan (Fandy, 1996, Fandy, 2000). Pembuatan usulan pembuatan program peningkatan kualitas melalui atribut kepentingan yang dinginkan konsumen serta brainstorming pihak perusahaan (Rumintang, 2001). Selanjutnya, Penyebaran kuisioner (bagan 2) dengan prolog program peningkatan kualitas disebutkan dibagian atas kuisioner. Setelah dibuat usulan perbaikan kualitas tersebut, maka disusun kuisioner bagian kedua yang berisi pernyataan tentang usulan proram perbaikan kualitas terseut apabila dilakukan apakah akan mengubah kepuasan konsumen. Kemudian kuisioner tersebut di sebar kepada konsumen atau responden yang sama dengan responden pada saat kuisioner bagian 1 .

Perhitungan Customer Satisfaction Index (CSI) bagian kedua. Setelah disebar dan mendapatkan data tersebut maka dilakukan perhitungan CSI bagian kedua. Hal ini untuk mengetahui apakah terjadi perubahan nilai kepuasan konsumen. Apabila tidak terjadi maka langkah selanjutnya adalah membuat kembali usulan perbaikan kualitas yang lain.

Setelah diketahui bahwa nilai kepuasan konsumen akan program perbaikan kualitas yang diusulkan tersebut meningkat, langkah slanjutnya adalah mengetahui laju retensi pelanggan baru yang didapat setelah diketahui bahwa terjadi peningkatan kepuasan konsumen terhadap usulan program perbaikan kualitas apabila itu akan dilaksanakan. Pengambilan data di perusahaan berupa data pertumbuhan pasar tahun 2006-2009 di asuransi Bumiputera Sidoarjo dan data pangsa pasar perusahaan tahun 2007-2009.

Setelah pengambilan data dari perusahaan tersebut dilaksanakan, maka kemudian dilakukan 
perhitungan prosentase pangsa pasar, hal ini dilakukan untuk mengetahui besar prosentase pangsa pasar selama beberapa periode ke depan.

Selanjutnya mengkalkulasikan estimasi biaya pada masing-masing alternatif-alternalit program peningkatan kualitas. Kemudian menghitung nilai NPV, NPVo, dan NPVAS (Roland, 1995). Tahap ini dihitung nilai NPV yang didapat berdasarkan data kalkulasi biaya perbaikan kualitas yang diusulkan, dan NPV sebelum perbaikan kualitas (NPVo), serta selisih dari biaya yang dikeluarkan sebelum program perbaikan kualitas dengan biaya program sesudah perbaikan kualitas (NPVAS) kemudian nilai ROQ dihitung dengan menggunakan data nilai NPV, NPVo, dan NPVAS. (Kristanti, 2007) Tahap analisa dan kesimpulan. Analisa perbaikan kualitas dan analisa sensitifitas. Tahap dianalisa berdasar nilai ROQ, apakah program perbaikan kualitas tersebut dapat diimplementasikan dengan kaidah-kaidah ROQ yang ada dan analisa perubahan nilai (sensitifitas).

\section{HASIL DAN PEMBAHASAN}

\section{Penyebaran kuisioner}

Kuisioner disebar sebanyak 35 kuisioner sebagai kuisioner awal yang diisi oleh nasabah AJB Bumiputera 1912 cabang Sidoarjo. Dari penyebaran kuisioner yang telah dilakukan didapat 2 kuisioner yang dianggap gagal, hal ini disebabkan kuisioner tersebut tidak diisi oleh responden (nasabah) secara lengkap.

\section{Pemetaan Importance and performance}

Pemetaan Importance and performance, diperoleh hasil perhitungan nilai rata-rata masing-masing atribut sbb:

$$
\begin{aligned}
& \overline{\bar{X}}=\frac{\sum_{i=1}^{k} \bar{X} i}{n}=\frac{3,759+3,940+\ldots .+3,843}{16}=4,020 \\
& \overline{\bar{Y}}=\frac{\sum_{i=1}^{k} \bar{Y} i}{n}=\frac{3,410+3,301+\ldots .+3,735}{16}=3,594
\end{aligned}
$$

\section{Perhitungan CSI (Customer Satisfaction Index)}

Customer Satisfaction Index (CSI) digunakan untuk tingkat kepuasan konsumen secara menyeluruh dengan melihat tingkat kepentingan dari aribut atau jasa.

Kriteria nilai CSI adalah sebagai berikut:
Tabel 1. Tingkat kepentingan \& kinerja

\begin{tabular}{ccccccc}
\hline \multirow{2}{*}{ No. } & \multirow{2}{*}{ Atribut } & \multicolumn{2}{c}{ Total Nilai } & \multicolumn{2}{c}{ Rata-rata } & \multirow{2}{*}{ KUADRAN } \\
\cline { 3 - 6 } & & Kepuasan & Kepentingan & $\bar{X}$ & $\bar{Y}$ & \\
\hline 1 & V1 & 312 & 283 & 3,759 & 3,41 & 3 \\
\hline 2 & V2 & 327 & 274 & 3,94 & 3,301 & 3 \\
\hline 3 & V3 & 329 & 275 & 3,964 & 3,313 & 3 \\
\hline 4 & V4 & 335 & 286 & 4,036 & 3,446 & 4 \\
\hline 5 & V5 & 361 & 260 & 4,349 & 3,133 & 4 \\
\hline 6 & V6 & 364 & 304 & 4,386 & 3,663 & 2 \\
\hline 7 & V7 & 322 & 298 & 3,88 & 3,59 & 3 \\
\hline 8 & V8 & 339 & 335 & 4,084 & 4,036 & 2 \\
\hline 9 & V9 & 319 & 314 & 3,843 & 3,783 & 1 \\
\hline 10 & V10 & 334 & 301 & 4,024 & 3,627 & 2 \\
\hline 11 & V11 & 310 & 296 & 3,735 & 3,566 & 3 \\
\hline 12 & V12 & 355 & 310 & 4,277 & 3,735 & 2 \\
\hline 13 & V13 & 343 & 294 & 4,133 & 3,542 & 4 \\
\hline 14 & V14 & 328 & 301 & 3,952 & 3,627 & 1 \\
\hline 15 & V15 & 342 & 332 & 4,12 & 4 & 2 \\
\hline 16 & V16 & 319 & 310 & 3,843 & 3,735 & 1 \\
\hline
\end{tabular}

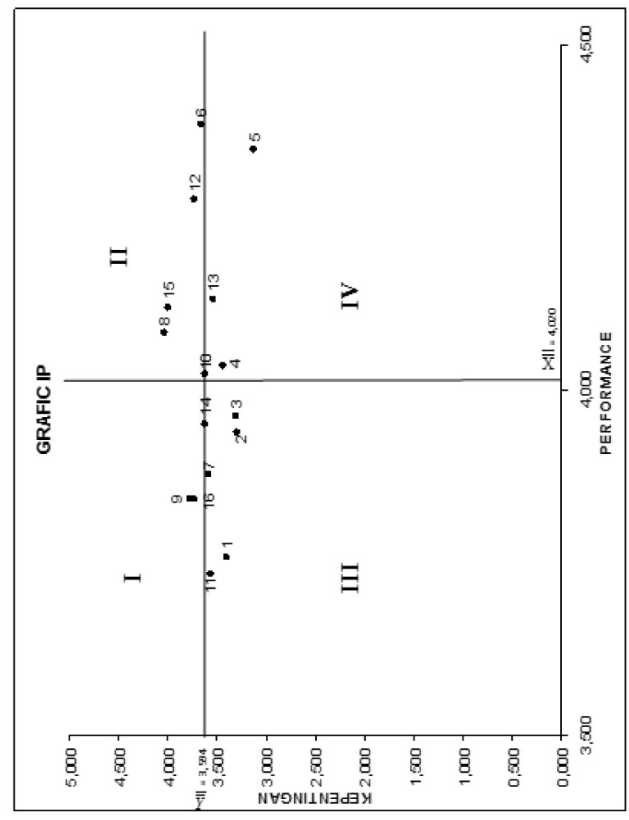

Gambar 1. Pemetaan grafik IP (ImportancePerformance)

\begin{tabular}{|c|c|c|}
\hline Kuadran & Atribut & Penjelasan atribut \\
\hline \multirow{3}{*}{1} & 9 & Kemudahan dan ketepatan pengajuan dan pembayaran klaim \\
\hline & 14 & Agen mengetahui dan mengerti produk dan jasa yang ditawarkan \\
\hline & 16 & Adanya bonus atau hadiah yang menarik bagi nasabah \\
\hline \multirow{5}{*}{2} & 6 & Produk yang ditawarkan sesuai dengan kebutuhan konsumen \\
\hline & 8 & Kemudahan melakukan transaksi pembayaran \\
\hline & 10 & Kecepatan respon dari karyawan (Tanggapan terhadap klaim) \\
\hline & 12 & Adanya jaminan keamanan dan kerahasiaan dana yang disimpan \\
\hline & 15 & Pemberian informasi melalui situs (web site) \\
\hline \multirow{5}{*}{3} & 1 & Kebersihan dan kerapian kantor perusahaan \\
\hline & 2 & Penampilan karyawan/karyawati perusahaan \\
\hline & 3 & Ketersediaan tempat parkir yang luas dan aman \\
\hline & 7 & Keakuratan data dan informasi yang diberikan \\
\hline & 11 & Kecepatan pelayanan yang diberikan \\
\hline \multirow{3}{*}{4} & 4 & Jumlah teller yang memadai \\
\hline & 5 & $\begin{array}{l}\text { Ketersediaan ruang tunggu yang nyaman (ruangan ber-AC dan } \\
\text { luas) }\end{array}$ \\
\hline & 13 & Keramahan komunikasi dari karyawan menghadapi konsumen \\
\hline
\end{tabular}

Tabel 2. Atribut kepuasan konsumen 
Tabel 3. Kriteria nilai CSI

\begin{tabular}{cl}
\hline Nilai CSI & \multicolumn{1}{c}{ Kriteria CSI } \\
\hline $0,81-1,00$ & Sangat puas \\
$0,66-0,80$ & Puas \\
$0,51-0,65$ & Cukup Puas \\
$0,35-0,50$ & Kurang Puas \\
$0,00-0,34$ & Tidak Puas \\
\hline
\end{tabular}

Untuk mengetahui besarnya CSI, maka dapat dilakukan langkah-langkah seperti dalam rumus di teori, doperoleh nilai:

$$
\begin{aligned}
\text { CSI } & =\frac{23,8373+23,0792+\ldots+26,1115}{5}=0,8041 \\
& =80,41 \%
\end{aligned}
$$

Sehingga didapat niali CSI adalah sebesar 0,8041 $(80,41 \%)$, maka dengan nilai tersebut menjelaskan bahwa kepuasan konsumen adalah sebesar $80 \%$. Jika dihubungkan dengan nilai kriteria CSI, maka AJB BUMIPUTERA 1912 Cabang Sidoarjo memiliki nilai kepuasan konsumen dengan predikat memuaskan (Puas).

\section{Retensi pelanggan}

Perhitungan retensi pelanggan sangat ditentukan besarnya nilai repurchase intention atau jumlah nasabah yang akan menggunakan kembali produk atau jasa yang diberikan perusahaan.

Tabel 4. Nilai repurchase intention awal

\begin{tabular}{lcccc}
\hline & \multirow{2}{*}{ Jumlah } & \multirow{2}{*}{$\%$} & \multicolumn{2}{c}{ Repurchase Intantion } \\
\cline { 4 - 5 } & & & Count & $\%$ \\
\hline Tidak Puas (3) & 10 & 12,05 & 0 & 0,00 \\
Puas (2) & 44 & 53,01 & 24 & 61,54 \\
Sangat Puas (1) & 29 & 34,94 & 15 & 38,46 \\
\hline Jumlah & 83 & Jumlah & 39 & \\
\hline
\end{tabular}

S : Prosentase pelanggan yang puas dengan pelayanan secara keseluruhan $=\frac{44}{83} \times 100 \%$ $=53,01 \%=0,5301$

D : Prosentase pelanggan yang terkesan dengan pelayanan secara keseluruhan $=\frac{29}{83} \times 100 \%$ $=34,94 \%=0,3494$

R1: Laju retensi untuk kelompok tidak puas $=0 \%$ $=0$

R2: Laju retensi untuk kelompok yang puas $=\frac{24}{39} \times 100 \%=61,54 \%=0,6154$

R3: laju retensi untuk kelompok yang terkesan $=\frac{15}{39} \times 100 \%=38,46 \%=0,3846$

Rumus retensi adalah, $R^{\prime}=(1-S) R_{1}+S R_{2}+D\left(R_{3}-R_{2}\right)$, sehingga perhitungan retensi pelanggan adalah sebagai berikut:

$$
\begin{aligned}
R^{\prime} & =(1-0,5301) 0+(0,6154)(0,5301)+0,3494(0,3846-0,6154) \\
& =0,2456
\end{aligned}
$$

Sehingga nilai retensi pelanggan adalah 0,2456 atau $24,56 \%$.

Tabel 5. Usulan program peningkatan kualitas

\begin{tabular}{cll}
\hline No. & \multicolumn{1}{c}{$\begin{array}{c}\text { Atribut prioritas utama } \\
\text { perbaikan kualitas }\end{array}$} & Usulan program perbaikan kualitas \\
\hline 1. & $\begin{array}{l}\text { Kemudahan dan ketepatan } \\
\text { pengajuan dan pembayaran klaim } \\
\text { (V9) }\end{array}$ & $\begin{array}{l}\text { Sistem pengajuan dan pembayaran } \\
\text { klaim online (sistem ATM). }\end{array}$ \\
\hline 2. & $\begin{array}{l}\text { Karyawan mengetahui dan } \\
\text { mengerti produk dan jasa yang } \\
\text { ditawarkan (V14) }\end{array}$ & $\begin{array}{l}\text { Trainning karyawan tentang } \\
\text { pengenalan produk dan jasa yang akan } \\
\text { ditawarkan kepada nasabah. }\end{array}$ \\
\hline & $\begin{array}{l}\text { Adanya bonus atau hadiah yang } \\
\text { menarik bagi nasabah (V16) }\end{array}$ & $\begin{array}{l}\text { Pembarian bonus kepada nasabah } \\
\text { berupa mobil, sepeda motor, televisi, } \\
\text { dan uang tunai (cash back). }\end{array}$ \\
\end{tabular}

\section{Perhitungan CSI bagian kedua}

Setelah kuisioner bagian kedua yang berisi program perbaikan kualitas tersebut disebar, maka perlu diketahui nilai kepuasan konsumennya. Apakah setelah dilakukan perbaikan kualitas, kepuasan konsumen akan meningkat, maka digunakan perhitungan CSI (Customer Satisfaction Index) untuk mengetahuinya. Perhitungan Customer Satisfaction Index (CSI) pada bagian kedua, memiliki cara serta iterasi pengerjaan yang sama dengan perhitungan CSI pada bagian pertama.

Sehingga didapat nilai CSI adalah sebesar 0,8122 (81\%) yaitu memuaskan. Nilai tersebut menunjukan peningkatan nilai kepuasan konsumen dari sebelum dilakukan program perbaikan kualitas yaitu 80,41\% menjadi setelah dilakukan program perbaikan kualitas yaitu $81,22 \%$. Maka dengan nilai tersebut menjelaskan bahwa program perbaikan kualitas yang ditawarkan dapat meningkatkan kepuasan konsumen.

\section{Perhitungan laju retensi baru}

Setelah mengetahui bahwa program perbaikan kualitas yang diusulkan dapat meningkatkan kepuasan konsumen, maka perlu diketahui retensi pelanggan baru akibat program perbaikan kualitas tersebut.

Tabel 6. Nilai repurchase intention setalah perbaikan

\begin{tabular}{lcccc}
\hline & \multirow{2}{*}{ Jumlah } & \multirow{2}{*}{$\%$} & \multicolumn{2}{c}{ Repurchase Intantion } \\
\cline { 4 - 5 } & & & Count & $\%$ \\
\hline Tidak Puas (1) & 5 & 6,02 & 0 & 0,00 \\
Puas (2) & 49 & 59,04 & 26 & 63,41 \\
Sangat Puas (3) & 29 & 34,94 & 15 & 36,59 \\
\hline Jumlah & 83 & Jumlah & 41 & \\
\hline
\end{tabular}

S :0,5904; D : 0,3494; R1: \%; R2: 63,41\%; R3: 36,59\%; $\mathrm{R}=0,2856$ 
Sehingga nilai retensi pelanggan adalah 0,2856 atau $28,56 \%$. Maka diketahui pula yaitu terjadi peningkatan retensi pelanggan akibat program perbaikan kualitas yang diusulkan, dari $24,56 \%$ menjadi $28,56 \%$.

\section{Perhitungan prosentase pangsa pasar}

\section{Nilai Churn (c)}

Churn adalah prosentase pelanggan yang meninggalkan pasar setiap periode.

Tabel 7. Prosentase pangsa pasar

\begin{tabular}{lrccc}
\hline \multirow{2}{*}{$\begin{array}{c}\text { Repurchase } \\
\text { Intantion }\end{array}$} & \multicolumn{3}{c}{ Rekomendasi } & \\
\cline { 2 - 4 } & Ya (3) & $\begin{array}{c}\text { Belum } \\
\text { tentu (2) }\end{array}$ & Tidak (1) & Jumlah \\
\hline Ya (3) & 21 & 17 & 3 & 41 \\
Belum tentu (2) & 6 & 16 & 7 & 29 \\
Tidak (1) & 2 & 7 & 4 & 13 \\
\hline Jumlah & 29 & 40 & 14 & 83 \\
\hline
\end{tabular}

Maka $c$ (Churn) dapat dirumuskan sebagai berikut:

Jumlah responden (nasabah) yang tidak menggunakan kembali produk jasa

layanan perusahaan kembali serta tidak merekomendasikan produk/jasa layanan $c=\frac{\text { perusahaan kepada orang lain }}{\text { Total responden }}$ $c=\frac{4}{83} \times 100 \%=0,0482=4,82 \%$

Sehingga nilai churn adalah $4,82 \%$

\section{Faktor pertumbuhan pasar $(\mathbf{G})$}

Faktor pertumbuhan pasar $(\mathrm{G})=1+\mathrm{g}$, di mana $\mathrm{g}$ adalah nilai pertumbuhan pasar. Nilai g didapat dari data pangsa pasar yang didapat dari perusahaan dari 2 tahun terakhir (Tabel 7).

Sehingga nilai g adalah sebagai berikut:

$$
\begin{aligned}
\mathrm{g} & =\frac{\left[\frac{(\text { Market size th } 2009-\text { Market size th 2008) }}{\text { Market size th } 2008}\right]}{2} \\
& =\frac{\left[\frac{(160560-153286)}{153286}\right]}{2}=0,0475=4,75 \%
\end{aligned}
$$

Maka didapat nilai G (Faktor pertumbuhan pasar) adalah $1+\mathrm{g}$.

$\mathrm{G}=1+0,0475=1,0475$

\section{Firm's attractiveness (A)}

Firm's attractiveness (A) adalah Seberapa banyak pelanggan baru yang dapat ditarik perusahaan. Sehingga dalam perhitungan pencarian nilai A, perlu menggunakan data pertumbuhan pasar yang didapat dari perusahaan. Dengan menggunakan rumus:

Pelanggan baru $=\mathrm{A}_{\mathrm{t}-1}(\mathrm{GNt}-(1-\mathrm{c}) \mathrm{Nt})$

$$
\mathrm{A}_{\mathrm{t}-1}=\frac{\text { Pelanggan baru }}{(1(\mathrm{GNt}-(1-\mathrm{c}) \mathrm{Nt}))}
$$

Sehingga banyaknya pelanggan baru yang dapat ditarik perusahaan adalah sebesar $0,21 \%$.

\section{Retensi pelanggan perusahaan pesaing $\left(R^{\prime} t\right)$}

Retensi pelanggan pesaing didapat dengan menggunakan rumus:

$M_{t+1}=\frac{\left[R_{t} M_{t}+\left(1-R_{t}^{\prime}-c\right)\left(1-M_{t}\right)+A_{t-1}(G-1+c)\right]}{G}$

Rt adalah retensi pelanggan. Dalam hal ini adalah retensi pelanggan setelah dilakukan program perbaikan kualitas sehingga $\mathrm{Rt}=28,06 \%$. Retensi pelanggan pesaing adalah sebesar 90,23\%. Kemudian dihitung nilai pangsa pasar selama 5 periode perencanaan, baik saat sebelum dilakukan perbaikan kualitas maupun setelah dilakukan perbaikan kualitas.

Tabel 8. Perbandingan nilai pangsa pasar awal \& pangsa pasar baru.

\begin{tabular}{cccccc}
\hline \multirow{2}{*}{ Periode } & \multirow{2}{*}{ Tahun } & \multicolumn{2}{c}{ Sebelum perbaikan kualitas } & \multicolumn{2}{c}{ Setelah perbaikan kualitas } \\
\cline { 3 - 6 } & & Pangsa pasar & Ukuran pasar & Pangsa pasar & Ukuran pasar \\
\hline 1 & 2010 & 0,05850624 & 170234 & 0,060521635 & 170234 \\
\hline 2 & 2011 & 0,058179426 & 180194 & 0,060581227 & 180536,8401 \\
\hline 3 & 2012 & 0,058118231 & 190677 & 0,060594378 & 191473,9833 \\
\hline 4 & 2013 & 0,058106773 & 201759 & 0,060597281 & 203076,2302 \\
\hline 5 & 2014 & 0,058104628 & 213483 & 0,060597921 & 215382,0975 \\
\hline
\end{tabular}




\section{Kalkulasi estimasi biaya-biaya program perbaikan kualitas Sistem pengajuan dan pembayaran klaim Online (sistem ATM)}

Tabel 9. Rekapitulasi biaya sistem ATM

\begin{tabular}{|c|c|c|c|c|c|}
\hline No. & $\begin{array}{c}\text { Macam-macam biaya yang } \\
\text { diperlukan }\end{array}$ & Jumlah & Satuan & Biaya & Total \\
\hline 1 & $\begin{array}{l}\text { Biaya pembuatan database online } \\
\text { perusahaan mengenai pengajuan } d \\
\text { pembayaran klaim }\end{array}$ & 1 & jaringan & $\begin{array}{c}\mathrm{Rp} \\
10.000 .000,00\end{array}$ & $\begin{array}{c}R p \\
10.000 .000,00\end{array}$ \\
\hline 2 & $\begin{array}{l}\text { Biaya pembuatan automatic } \\
\text { teller and confirm machine } \\
\text { (ATCM) diseluruh wilayah } \\
\text { Sidoarjo }\end{array}$ & 30 & Buah & $\begin{array}{c}\mathrm{Rp} \\
9.000 .000,00\end{array}$ & $\begin{array}{c}\mathrm{Rp} \\
270.000 .000,00\end{array}$ \\
\hline 3 & $\begin{array}{l}\text { Biaya sosialisasi dan promosi } \\
\text { sistem klaim ATCM }\end{array}$ & - & - & $\begin{array}{c}\mathrm{Rp} \\
8.000 .000,00\end{array}$ & $\begin{array}{c}\mathrm{Rp} \\
8.000 .000,00\end{array}$ \\
\hline 4 & $\begin{array}{l}\text { Biaya perekrutan pegawai baru } \\
\text { untuk proyek database online }\end{array}$ & 5 & orang & $\begin{array}{c}\mathrm{Rp} \\
2.000 .000,00\end{array}$ & $\begin{array}{c}\mathrm{Rp} \\
10.000 .000,00\end{array}$ \\
\hline 5 & $\begin{array}{l}\text { Biaya trainning karyawan baru } \\
\text { yang proyek database online }\end{array}$ & 5 & orang & $\begin{array}{c}\mathrm{Rp} \\
5.000 .000,00\end{array}$ & $\begin{array}{c}\mathrm{Rp} \\
25.000 .000,00\end{array}$ \\
\hline 6 & $\begin{array}{l}\text { Biaya gaji karyawan baru proyek } \\
\text { database online }\end{array}$ & 5 & orang & $\begin{array}{c}\mathrm{Rp} \\
975.000,00\end{array}$ & $\begin{array}{c}\mathrm{Rp} \\
4.875 .000,00\end{array}$ \\
\hline \multicolumn{5}{|c|}{ Total biaya awal (F') } & $\begin{array}{c}\mathrm{Rp} \\
327.875 .000,00\end{array}$ \\
\hline 1 & $\begin{array}{l}\text { Biaya perawatan ATCM } \\
\text { diseluruh sidoarjo }\end{array}$ & 30 & buah & $\begin{array}{c}\mathrm{Rp} \\
5.000 .000,00\end{array}$ & $\begin{array}{c}\mathrm{Rp} \\
150.000 .000,00\end{array}$ \\
\hline 2 & Biaya sosialisasi tahunan ATCM & - & - & $\begin{array}{c}\mathrm{Rp} \\
2.000 .000,00\end{array}$ & $\begin{array}{c}\mathrm{Rp} \\
2.000 .000,00\end{array}$ \\
\hline 3 & $\begin{array}{l}\text { Biaya gaji karyawan } \\
\text { pengoperasi database online }\end{array}$ & 5 & orang & $\begin{array}{c}\mathrm{Rp} \\
975.000,00\end{array}$ & $\begin{array}{c}\mathrm{Rp} \\
4.875 .000,00\end{array}$ \\
\hline 4 & $\begin{array}{l}\text { Biaya pemeliharaan dan } \\
\text { penambahan banwitch data base }\end{array}$ & 1 & jaringan & $\begin{array}{c}R p \\
3.000 .000,00\end{array}$ & $\begin{array}{c}R p \\
3.000 .000,00\end{array}$ \\
\hline \multicolumn{5}{|c|}{ Total biaya yang dikeluarkan tiap tahun (F) } & $\begin{array}{c}\mathrm{Rp} \\
159.875 .000,00\end{array}$ \\
\hline
\end{tabular}

Training karyawan tentang pengenalan produk dan jasa yang akan ditawarkan kepada nasabah.

Tabel 10. Rekapitulasi biaya training karyawan

\begin{tabular}{cccccc}
\hline No. & $\begin{array}{c}\text { Macam-macam biaya yang } \\
\text { diperlukan }\end{array}$ & Jumlah & Satuan & Biaya & Total \\
\hline 1 & $\begin{array}{l}\text { Trainning karyawan tentang } \\
\text { produk/jasa yang akan } \\
\text { ditawarkan }\end{array}$ & 10 & karyawan & $\begin{array}{c}\mathrm{Rp} \\
3.000 .000,00\end{array}$ & $\begin{array}{c}\mathrm{Rp} \\
30.000 .000,00\end{array}$ \\
\hline \multicolumn{2}{c}{ Total biaya awal (F') } & & $\begin{array}{c}\mathrm{Rp} \\
30.000 .000,00\end{array}$
\end{tabular}

Karena pada program perbaikan kualitas ini tidak menggunakan biaya tiap tahun, maka untuk nilai $\mathrm{F}$ pada program perbaikan kualitas ini adalah Rp. 0,00. Pemberian bonus kepada nasabah berupa mobil dan sepeda motor

Tabel 11. Rekapitulasi biaya pemberian bonus

\begin{tabular}{|c|c|c|c|c|c|}
\hline No. & $\begin{array}{l}\text { Macam-macam biaya yang } \\
\text { diperlukan }\end{array}$ & Jumlah & satuan & Biaya & Total \\
\hline 1 & $\begin{array}{l}\text { Biaya pembelian bonus } \\
\text { (hadiah) berupa mobil kijang } \\
\text { innova }\end{array}$ & 1 & buah & $\begin{array}{c}\mathrm{Rp} \\
285.100 .000,00\end{array}$ & $\begin{array}{c}\mathrm{Rp} \\
285.100 .000,00\end{array}$ \\
\hline 2 & $\begin{array}{l}\text { Biaya pembelian bonus } \\
\text { (hadiah) berupa sepeda motor } \\
\text { honda revo }\end{array}$ & 20 & buah & $\begin{array}{c}\mathrm{Rp} \\
11.600 .000,00\end{array}$ & $\begin{array}{c}R p \\
232.000 .000,00\end{array}$ \\
\hline 3 & $\begin{array}{l}\text { Biaya promosi untuk bonus } \\
\text { (hadiah) }\end{array}$ & - & - & $\begin{array}{c}\mathrm{Rp} \\
9.000 .000,00\end{array}$ & $\begin{array}{c}\mathrm{Rp} \\
9.000 .000,00\end{array}$ \\
\hline \multicolumn{5}{|c|}{ Total biaya awal (F') } & $\begin{array}{c}\mathrm{Rp} \\
526.100 .000,00\end{array}$ \\
\hline 1 & $\begin{array}{l}\text { Biaya pembelian bonus } \\
\text { (hadiah) berupa mobil kijang } \\
\text { innova }\end{array}$ & 1 & buah & $\begin{array}{c}\mathrm{Rp} \\
285.100 .000,00\end{array}$ & $\underset{285.100 .000,00}{\mathrm{Rp}}$ \\
\hline 2 & $\begin{array}{l}\text { Biaya pembelian bonus } \\
\text { (hadiah) berupa sepeda motor } \\
\text { honda revo }\end{array}$ & 20 & buah & $\begin{array}{c}\mathrm{Rp} \\
11.600 .000,00\end{array}$ & $\begin{array}{c}\mathrm{Rp} \\
232.000 .000,00\end{array}$ \\
\hline 3 & $\begin{array}{l}\text { Biaya promosi untuk bonus } \\
\text { (hadiah) }\end{array}$ & - & - & $\begin{array}{c}\mathrm{Rp} \\
1.000 .000,00\end{array}$ & $\begin{array}{c}\mathrm{Rp} \\
1.000 .000,00\end{array}$ \\
\hline \multicolumn{5}{|c|}{ Total biaya yang dikeluarkan tiap tahun (F) } & $\begin{array}{c}\mathrm{Rp} \\
518.100 .000,00 \\
\end{array}$ \\
\hline
\end{tabular}

Sehingga didapat dari kesuruhan biaya adalah:

1. Total biaya awal dari kesuruhan biaya ( $\left.F^{\prime}\right)$ adalah: $\mathrm{F}^{\prime}=$ Rp. 833.975.000,00

2. Total biaya yang dikeluarkan setiap tahun dari seluruh biaya ( $\mathrm{F}$ ) adalah: $\mathrm{F}=$ Rp. $677.975 .000,00$

\section{Perhitungan NPV, NPV0, NPVAS dan ROQ Perhitungan NPV}

Perhitungan Net Present Value dengan menggunakan data-data setelah dilakukan program perbaikan kualitas.

Rumus NPV adalah sebagai berikut:

$N P V=\sum_{k=1}^{p}(1+I)^{-k}\left[Y M_{t+k}(1+G)^{k} N_{t+k}-X_{t+k}\right]$

Tabel 12. Perhitungan NPV

\begin{tabular}{ccccccc}
\hline Periode & I & Y & G & Mtk & Nt & NPV \\
\hline 1 & 0,0825 & 250000 & 1,047453779 & 0,060522 & 170234 & 4871729528 \\
\hline 2 & 0,0825 & 250000 & 1,047453779 & 0,060581 & 180537 & 9781744402 \\
\hline 3 & 0,0825 & 250000 & 1,047453779 & 0,060594 & 191474 & 19626403230 \\
\hline 4 & 0,0825 & 250000 & 1,047453779 & 0,060597 & 203076 & 39372867162 \\
\hline 5 & 0,0825 & 250000 & 1,047453779 & 0,060598 & 215382 & 78983857966 \\
\hline & & & & & $\begin{array}{c}\text { NPV } \\
\text { total }\end{array}$ & $\mathbf{1 5 2 6 3 6 6 0 2 2 8 9}$ \\
\cline { 4 - 6 } & & & & & &
\end{tabular}

\section{Perhitungan NPVO (NPV sebelum perbaikan kualitas)}

Rumus NPV0 sama dengan rumus NPV. Namun data yang digunakan adalah data sebelum dilakukan perbaikan kualitas.

Rumus yang digunakan adalah:

$N P V=\sum_{k=1}^{p}(1+I)^{-k}\left[Y M_{t+k}(1+G)^{k} N_{t+k}-X_{t+k}\right]$

Tabel 13. Perhitungan NPV awal

\begin{tabular}{ccccccc}
\hline Periode & I & Y & G & Mtk & Nt & NPV \\
\hline 1 & 0,0825 & 250000 & 1,047453779 & 0,058506 & 170234 & 4709498931 \\
\hline 2 & 0,0825 & 250000 & 1,047453779 & 0,058179 & 180194 & 9376085726 \\
\hline 3 & 0,0825 & 250000 & 1,047453779 & 0,058118 & 190677 & 18746061743 \\
\hline 4 & 0,0825 & 250000 & 1,047453779 & 0,058107 & 201759 & 37509805277 \\
\hline 5 & 0,0825 & 250000 & 1,047453779 & 0,058105 & 213483 & 75066206520 \\
\hline \multicolumn{1}{r}{} & & & NPV0 & $\mathbf{1 4 5 4 0 7 6 5 8 1 9 7}$ \\
\cline { 5 - 6 } & & & & &
\end{tabular}

\section{Perhitungan NPVAS (Net Present Value Additional spandin)}

Perhitungan NPVAS adalah sebagai berikut:

NPVAS $=F^{\prime}+\sum_{k=1}^{P}\left(F-F_{0}\right)(1+I)^{-k}$ 


$$
\begin{aligned}
\text { NPVAS }= & 833.975 .000+[\{677.975 .000-0)(1 \\
& \left.+0,0825)^{-1}\right\}+\{(677.975 .000-0)(1+ \\
& \left.0,0825)^{-2}\right\}+\{(677.975 .000-0)(1+ \\
& \left.0,0825)^{-3}\right\}+\left\{(677.975 .000-0)(1+0,0825)^{-}\right. \\
& \left.{ }^{4}\right\}+\left\{(677.975 .000-0)(1+0,0825)^{-5}\right\}
\end{aligned}
$$

NPVAS $=3.573 .189 .670$

Sehingga didapat nilai NPVAS adalah Rp. 3.573.189.670,00

\section{Perhitungan ROQ}

Dalam Kurniawan, 2007, rumus ROQ adalah:

$$
\begin{aligned}
& \mathrm{ROQ}=\left(\frac{\mathrm{NPV}-\mathrm{NPVO}}{\mathrm{NPVAS}}\right) \\
& \mathrm{ROQ}=2,0231
\end{aligned}
$$

Nilai ROQ adalah sebesar 2,0231 yaitu lebih besar dari 1, sehingga menurut teori analisa ROQ usulan program perbaikan kualitas tersebut layak untuk diimplementasikan

\section{SIMPULAN}

Investasi perbaikan kualitas pelayanan layak diimplementasikan karena dengan investasi tersebut terjadi peningkatan nilai kepuasan dari $80,41 \%$ menjadi $81,22 \%$, peningkatan nilai retensi pelanggan dari $24,56 \%$ menjadi $28,56 \%$.Kelayakan investasi ini ditandai oleh nilai Return On Quality(ROQ) sebesar 2,0231 (yang lebih besar dari 1) pada tingkat suku bunga maksimal $46,457 \%$.

\section{DAFTAR PUSTAKA}

Darmawan, B, 2000. Pengaruh Service Quality Perception terhadap Purchase Intention (Studi Empiris pada
Konsumen Supermarket Pasaraya Sri Ratu Madiun). Surabaya. ITS http://mmt.its.ac.id/library/wp-content/ uploads/2008/12/microsoft-word-3-budhi-darmawan. $p d f$

Gasperz, V., 2002. Menejemen Kualitas dalam Industri Jasa. Jakarta. Gramedia pustaka utama.

Hartono, SR. 1995. Hukum Asuransi dan Perusahaan Asuransi. Jakarta. Sinar grafika offset.

Kotler, P., 1996. Manajemen Pemasaran (Edisi Bahasa Indonesia, Jilid 1). Jakarta. Prenhalindo.

Kotler, P., 1999. Manajemen Pemasaran (Edisi Bahasa Indonesia, Jilid 2). Jakarta. Prenhalindo.

Kristanti, E., 2007. Peningkatan Kualitas Jasa Perhotelan Dengan Metode Return on Quality (Studi Kasus: Hotel Bali, Surabaya). Surabaya. ITS. www.ie.its. ac.id/downloads/abstrak/TA_776_Elsav.doc

Kurniawan, A., 2007. Analisa Loyalitas Pelanggan dan Perbaikan Proses Bisnis dengan Menggunakan Metode Return on Quality. Surabaya. ITS. www. ie.its.ac.id/downloads/abstrak/TA_746_ALDY.doc

Parasuranman A., dkk. 1990. Delivering Quality Service: Balancing Customer Perception and Expectation. London. Collier McMillan.

Roland T.R., 1995. Return on Quality (ROQ): Making Service Quality Financially Accountable. $h t t p: / / w w w$. rhsmith.umd.edu/Marketing/pdfs_docs/Article\%20R ust\%20JM\%200495.pdf

Rumintang, A., 2001. Strategi Penjualan Perumahan Sederhana (Studi Kasus: Perumahan Pejaya Anugrah Taman Sidoarjo). Surabaya. ITS

Syakira, 2009. Unsur Kepuasan Pasien. http://syakira-blog. blogspot.com/2009/01/unsur-kepuasan-pasien.html

Tjiptono F., 1996. Manajemen Jasa. Yogyakarta: Andi.

Tjiptono F., 2000. Prinsip-prinsip Total Quality Service. Yogyakarta: Andi. 